\title{
Detection of Aflatoxigenic and Non-Aflatoxigenic Isolates of Aspergillus flavus Isolated From Some Clinical and Environmental Sources by HPLC and PCR Techniques الاعتماد على استشراب السائل عالي الأداءو وتفاعل البلمرة المتسلسل في تحلد العزلات المنتجة للافلاتوكسين وغير

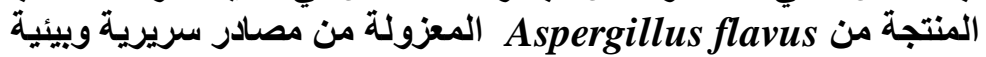

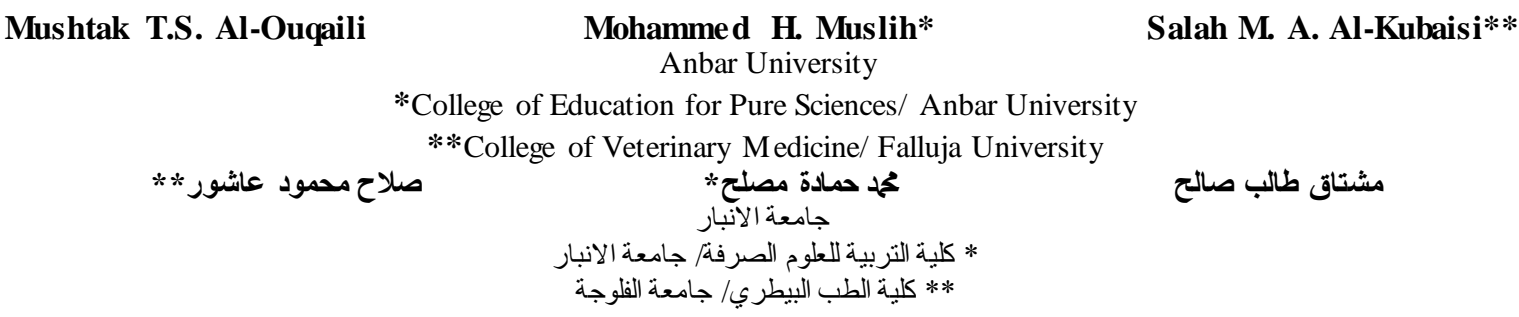

dr.mohammedh24@yahoo.com

\begin{abstract}
This study aimed to determine the role of polymerase chain reaction (PCR) and High-performance liquid chromatography (HPLC) technique in the discrimination between aflatoxigenic and non-aflatoxigenic isolates of Aspergillus flavus. The isolates were identified based on macroscopical and microscopical characteristics, and extracted aflatoxin was detected by HPLC technique. Furthermore, DNA was extracted from the all isolates and carried out by PCR to amplify target genes encoding for toxin production (nor-1, ver-1 and $a f l R)$. The results showed that the genes $(a f l R$, nor-1) were found in $11(73 \%)$ of isolates, while the (ver-1) gene appeared in $10(67 \%)$ of isolates. Both aflatoxigenic and nonaflatoxigenic isolates were also determined depending on the amplification of gene sites in the targeted DNA. HPLC technique has also used with high efficiency to ensure the aflatoxin-producing isolates and to evaluate the level of aflatoxin B1 production for 15 isolates of $A$. flavus. Ten isolates were able to produce aflatoxin with rates ranged from 0.78 to $45.03 \mathrm{ppm}$. PCR technique has proved high efficiency in the differentiation between aflatoxigenic and non-aflatoxigenic isolates of A. flavus. Moreover, aflatoxin production was directly associated with gene appearance and gene detection. Also, HPLC technique is a standard and superb technique in identifying and analyzing aflatoxin with high sensitivity and accuracy.
\end{abstract}

Keywords: Aflatoxin, Aspergillus, HPLC, PCR

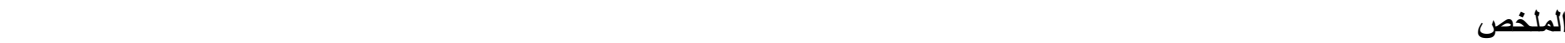

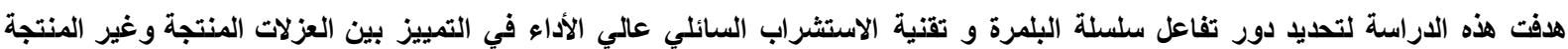

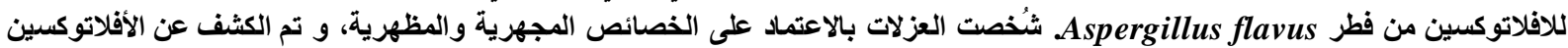

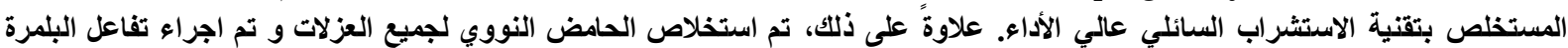
المتسلسل لتضخيم القطع المستهذفة (nor-1, ver-1 and aflR) التي تثفر لإنتاج الافلاتوكسين باستخدام تفاعل البلمرة المتسلسل أظهرت

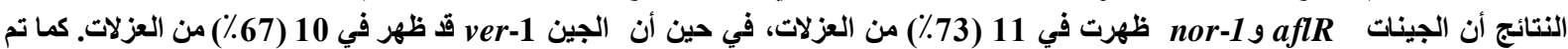

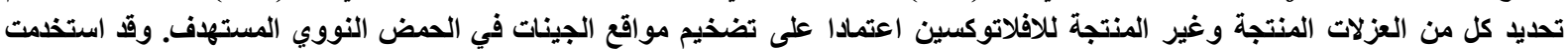

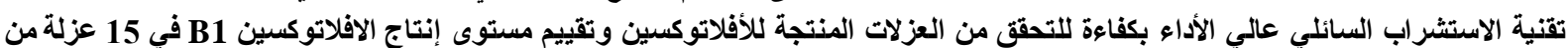

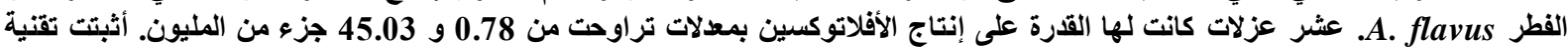

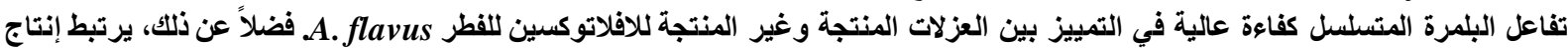

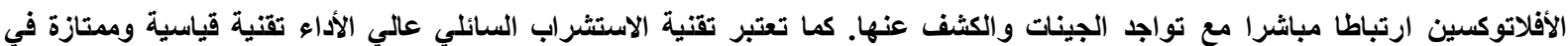

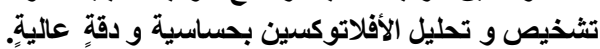

الكلمات الدالة: الافلاتوكسين، Aspergillus ، استثر اب السائل عالي الأداء، تفاعل البلمرة المتسلسل

\section{Introduction}

Aflatoxins as effective carcinogenic toxins are secondary metabolites produced by several species of Aspergillus-like Aspergillus flavus [1]. These toxins are important because they can colonize a range of economically important crops such as maize, nuts, tree nuts and peanuts. It appears in deterioration, bad odor, and discoloration and it may contaminate them with aflatoxin. Featuring these toxins have a high acute toxicity [2]. There are many factors affecting aflatoxin production during the storage period such as temperature, moisture, availability of oxygen, and fat content. There are four types of aflatoxins (B1, B2, G1, and G2) while

البحث مستل من رسالة ماجستير الباحث الثاني 
aflatoxin B1 is the toxic type which is more dangerous [3].

The cluster gene pathway for aflatoxin may allow all of the pathway genes to be expressed rapidly upon the appearance of secondary metabolites. Therefore, aflatoxins start to accumulate rapidly after 18 to $20 \mathrm{~h}$ of mycelial growth [4]. A distinction between aflatoxigenic and non-aflatoxigenic isolates of Aspergillus section Flavi has been a matter of controversy [5]. Conventional methods which used for detection of aflatoxins are microbiological identify, high-performance liquid chromatography (HPLC), thin layer chromatography (TLC) or enzyme-linked immunosorbent assay (ELISA). These procedures are time-consuming though they are considered reliable techniques in detection of aflatoxins [6]. However, polymerase chain reaction (PCR) is easy to be used, rapid and accurate [7] .

Because of the spread contamination of food products with A.flavus and the difficulty of access to a cut-off diagnostic tool for differentiation of aflatoxin producing isolates in addition to molecular screening and detection for aflatoxin encoding genes (ver-1, nor-1, and aflR). Thus, the aims of our study are to (1) determinate the capability of A. flavus isolated from clinical and environmental sources for production of aflatoxin B1, (2) differentiate between aflatoxigenic and non-aflatoxigenic isolates of the above fungus depending on PCR in addition to molecular detection for aflatoxin encoding genes (ver-1, nor-1 and $a f l R$ ), and (3) investigate the role of HPLC in analyzing and identifying aflatoxin B1 (AFB1) level produced from A. favus obtained from well extracted samples.

\section{Materials and methods}

\section{Identification of fungal isolates}

Fifteen A. flavus isolates were obtained from two laboratories; five (33\%) clinical isolates were obtained from the laboratory of College of Veterinary Medicine-University of Baghdad while 10.0 (67\%) environmental isolates were obtained from laboratories of the Environment and Water Department, Ministry of Science and Technology. These isolates were examined directly under the microscope using $10 \% \mathrm{KOH}$ and culturing on Sabauroud Dextrose Agar (SDA) and Potato Dextrose Agar (PDA) [8]. A. flavus isolates were cultured on SDA by the addition of $0.05 \mathrm{mg} / \mathrm{ml}$ Chloramphenicol to inhibit the growth of bacteria, then incubated at $28^{\circ} \mathrm{C}$ and $37^{\circ} \mathrm{C}$ and examined for seven days according to Duniere et al,. (2017). The isolates were identified depending on the species level based on macroscopical and microscopical characteristics using SDA [8] and scotch tape preparation [10]. All fungal isolates which identified as A. flavus were cultured and maintained in PDA supplemented with chloramphenicol and incubated for five days at $28 \pm 2{ }^{\circ} \mathrm{C}$ [11].

SDA slants were prepared and sterilized according to Lahouar et al., (2016). After that, chloramphenicol of 50 $\mathrm{mg} / \mathrm{l}$ was added. A loop was used for taking spores to implant in test tubes then incubated $28 \mathrm{C}$ for 7 days. After incubation of $10 \mathrm{ml}$ of sterile distilled water in culture tubes with A.flavus [13], the spores were harvested by sterile loop and suspension of spores was prepared in the tubes. After transferring and dilution of spore suspension, the spores were accounted in five $\mu \mathrm{L}$ by using a hemocytometer [14].

According to Lai et al., (2015), each flask was inoculated with million spores and incubated at $28 \pm 1{ }^{\circ} \mathrm{C}$ in the dark for 21 days and shaken once or twice daily for three days to aid in the even distribution of the inocula. After fermentation, the flasks were placed briefly in the oven at $60 \mathrm{C}$ for three hours to destroy the fungus.

\section{Extraction and detection of Aflatoxin B1 by HPLC}

Aflatoxin has been extracted according to Association Official Analytical Chemists 2000, procedure with few modifications as follows: 25 grams of rice powder who previously contaminated with A.flavus spores was added to $25 \mathrm{ml}$ of chloroform and water $(1: 1 \mathrm{v} / \mathrm{v})$. The contents of the flasks were shaken for 60 minutes. The crude extracts were filtered through gauze, and then through Whatman filter paper (No. 1). 25 ml of filtrate was mixed with $25 \mathrm{ml}$ methanol $90 \%$ and hexane at $(1: 1 \mathrm{v} / \mathrm{v})$ in a separate funnel for 10 minutes. The upper layer was discharged and the methanol lower layer was evaporated to near dryness and then $25 \mathrm{ml}$ chloroform/water (1:1 v/v) was added to the extract to another separate funnel. The funnel was shaken thoroughly for about 1 minute, then the lower layer chloroform passed through filter paper contained $10 \mathrm{~g}$ of anhydrous sodium sulfate. The last filtrate was evaporated to near dryness and the residue was stored in small dark vials at $5^{\circ} \mathrm{C}$ for chemical analysis. Aflatoxin B1 has been detected by high-performance liquid chromatography (HPLC) with the following conditions: column: 250x4.6mm, particle size $5 \mu \mathrm{m}$, ODS (C18), mobile phase acetonitrile: water 40:60 v/v, flow rate 1ml/ minute., detector UV-365nm and compared to standard aflatoxin B1 (Sigma) as control, as in Figure (2). 


\section{Extraction of total DNA from mycelia}

Total DNA was extracted from $0.5 \mathrm{~g}$ (wet weight) of mycelia after harvested, fungi growth was on enrichment culture (SDA) medium for 5 days. The mycelia/spores were frozen in liquid nitrogen which freezes the wall of the mycelia. After that, they transferred into a mortar to be milled in mycelia and crushed well. The temperature of liquid nitrogen was $-196^{\circ} \mathrm{C}$, and grinding continued for a 1 minute so that the fungus becomes a powder. A grounded sample was transferred into clean micro tubes with the capacity of $1.5 \mathrm{ml}$ [17]. Twenty $\mu 1$ of Proteinase K, cell lysis buffer was added to the samples and mixed thoroughly by vortex, and incubated at $60^{\circ} \mathrm{C}$ for 15 minutes to ensure the samples lysate and mix by vortex. Then, $100 \mu$ of the protein precipitation solution was added to the mixture, mixed by vortex immediately for 10 seconds. The mixture was incubated on ice for 5 minutes. The $1.5 \mathrm{ml}$ supernatant was transferred to new clean tubes containing room temperature Isopropanol. An aliquot of $300 \mu$ I Isopropanol was added and mixed thoroughly by vortexing for 20 times. The mixture was mixed by inversion and centrifuge at $15,000 \times \mathrm{g}$ for 2 minutes. Seventy $\%$ of room temperature ethanol was poured to the supernatant, and the mixture was centrifuged at $15,000 \times \mathrm{g}$ for 2 minutes. DNA Rehydration Solution was added. $1.5 \mu \mathrm{l}$ of RNase was added and incubated at $37^{\circ} \mathrm{C}$ for 15 minutes and Rehydrated at $65^{\circ} \mathrm{C}$ for 1 hour or overnight at $4{ }^{\circ} \mathrm{C}$. The purity and integrity of the isolated DNA were determined by NanoDrop Microvolume Spectrophotometers and agarose gel electrophoresis $1 \%$.The genomic isolation kit was provided by Promega kit, USA

Target genes and PCR reagents

Total DNA was used for detection of genes which encode to aflatoxin produce in A.flavus isolates, polymerase chain reaction (PCR) was conducted for amplifying three genes i.e. (ver-1, nor-1 and aflR). These genes and specific primer sequences have been selected from the already reported data [18]. The primer sequences, the name of genes and their product size are shown in Table 1. All PCR reagents were provided and synthesized by (Bioneer-Korea), Primers were scientifically designed thematically and all PCR attempts were carried out in PCR Thermal Cycler (Applied Biosystems).

Table (1): Primers used and their sequences

\begin{tabular}{|c|c|c|c|c|}
\hline No. & $\begin{array}{l}\text { Primers } \\
\text { Name }\end{array}$ & Sequence('5-'3) & $\begin{array}{l}\text { Product } \\
\text { size }\end{array}$ & References \\
\hline $\mathbf{1}$ & $\begin{array}{l}\operatorname{nor} 1 \\
(\text { aflD })\end{array}$ & $\begin{array}{l}\text { nor1 ACCGCTACGCCGGCACTCTCGGCAC } \\
\text { nor2 TTGGCCGCCAGCTTCGACACTCCG }\end{array}$ & 400 bp & Rashid et al., (2008) \\
\hline 2 & $\begin{array}{l}\text { ver } 1 \\
(\text { aflM })\end{array}$ & $\begin{array}{l}\text { ver1 GCCGCAGGCCGCGGAGAAAGTGGT } \\
\text { ver2 GGGGATATACTCCCGCGACACAGCC }\end{array}$ & $600 \mathrm{bp}$ & Rashid et al., (2008) \\
\hline 3 & $a f l R$ & $\begin{array}{l}\text { aflR1 TATCTCCCCCCGGGCATCTCCCGG } \\
\text { af1R2 CCGTCAGACAGCCACTGGACACGG }\end{array}$ & 1000 bp & Rashid et al., (2008) \\
\hline
\end{tabular}

\section{Optimization of PCR}

PCR reaction kit (premix) was selected from (Bioneer, Korea). The PCR reaction was carried out in $25 \mu 1$ solution containing $(5 \mu \mathrm{l}$ ) premix (Taq DNA polymerase, $250 \mu \mathrm{M}$ (each) dATP, dGTP, dCTP, dTTP and 1.5 $\mathrm{Mm} \mathrm{MgCl}$, reaction buffer ( $\mathrm{PH} 9$ ) and loading dye buffer (yellow and blue dye), $2 \mu \mathrm{l}$ each of amplification primers, $4 \mu \mathrm{l}$ target DNA, $12 \mu \mathrm{l}$ free nuclease water. Thermal cycle conditions were carried for these three genes Table (2). PCR amplified products were checked on $1 \%$ gel by gel electrophoresis and visualized under Gel documentation system [18].

Table (2): The PCR program which was used in the amplification of the targets DNA for: aflR, nor1 and ver 1 [18]

\begin{tabular}{lccc}
\hline \multicolumn{1}{c}{ Steps } & Temperature $\left({ }^{\circ} \mathbf{C}\right)$ & Time & \\
\hline Initial denaturation & 95 & 4 minutes & \\
Denaturation & 95 & 1 minute & 30 \\
Annealing & $58-62$ & 1 minute & cycles \\
Extension & 72 & 30 second & \\
Final extension & 72 & 10 minutes & \\
\hline
\end{tabular}


The Statistical Analysis System-SAS (2012) program was used to reveal the effect of different factors in study parameters. Chi-square test was used to compare between percentages and the least significant difference (LSD) between means [19].

\section{Results and discussion}

Isolates were cultured on two different types of media (SDA and PDA) for isolates conservation and all showed good growth. For more experiment, the A.flavus cultures were potato dextrose agar (PDA). To increase DNA amount and obtain pure colonies from A.flavus, enrichment method was adopted in which fungus from environmental and clinical sources was incubated on enrichment medium as explained by Quinn et al., (2013) was used which showed the remarkable growth of fungal mycelia in the form of powdery colonies on SDA media. The enrichment method was followed by DNA extraction from these fungal colonies, which was now readily extractable with high purity, for detection aflatoxigenic fungiby PCR .

Grains of rice were chosen as a culture media to diagnose aflatoxigenic and non-aflatoxigenic isolates growth by using HPLC approaches. The uninfected grains of rice were first artificially inoculated a definite number of spores (million spores) to examine whether the rice got affected by these fifteen A. flavus isolates.

All isolates on rice got infected effectively Figure (1). Only ten isolates were able to show aflatoxin product on rice which was confirmed by PCR in detection of genes (aflR, nor-1 and ver-1) that encoded aflatoxin. Some of the results are shown in Table (3).

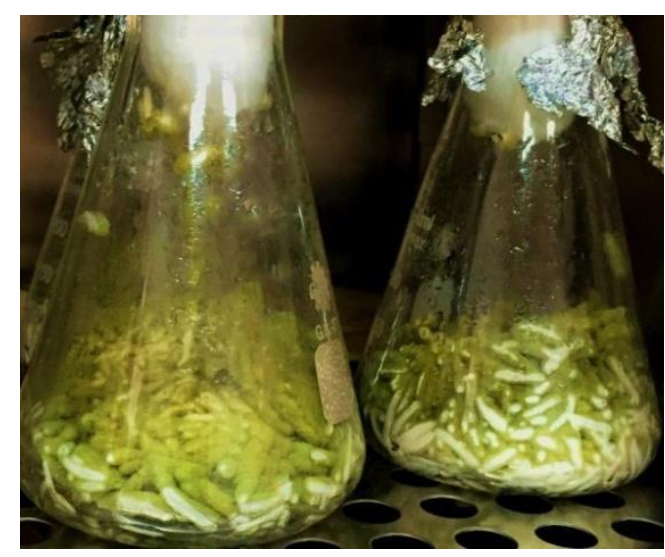

Fig. (1): Fluffy mycelia growth of A. flavus in $M E$ broth after incubation of 7 days

In the current study, we have found a fast, sensitive and specific technique to be used in the detection of aflatoxigenic and non-aflatoxigenic isolates taken from clinical and environmental sources. The strategy allows for processing a large number of samples in obtain results in the short time compared with conventional methods [21].

The results showed that out of 15 isolates, 11 (73\%) were positive for the aflR gene and nor- 1 gene, while 10 $(67 \%)$ isolates were positive for ver-1 gene. Also, amplification of nor-1 gene targeted by PCR and electrophoresis by agarose gel electrophoresis revealed that out of 15 isolates of A. flavus, 11 (73\%) isolates were positive for nor-1 gene, while four (27\%) isolates were negative as reflected in the following figure (2).

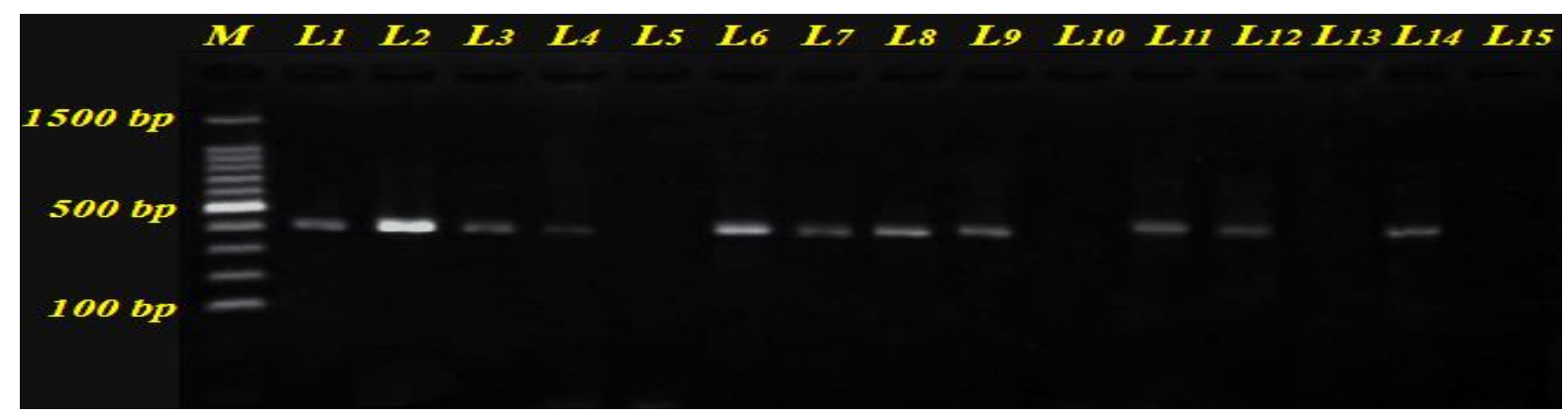

Fig. (2): PCR product with nor-1 primer (specific for nor-1) on $1 \%$ agarose gel electrophoresis with ethidium bromide, M: 100 bp DNA ladder. Lanes: AFl1, AFl2, AFl3, AFl4, AFl5, AFl6, AFl7, AFl8, AFl9, AFl10, AFl11, AFl12, AFl13, AFl14, AFl15. 
Aflatoxigenic isolates were the prevailing species of among all is olates [6]. This study was conducted because $A$. flavus was observed as the most commonly isolated from environmental and clinical sources [22]. Notwithstanding of this, no attempt was performed to identify aflatoxin producing species with using fast molecular techniques in clinical and environmental isolates [23]. The gene nor-1 plays a great role in the early conversion of the norsolorinic acid to averantin (in the middle of AF biosynthetic pathway), while other genes are involved in converting sterigmatocystin to AF in the last step of the aflatoxin pathway [24].

The absence of the genes encoding for aflatoxin production in A. flavus genome indicates the inability of this isolate to produce aflatoxin [25]. Moreover the non-aflatoxigenic isolates such as isolate (AFl1) lacking ver-1 gene. Whereas showed the presence of aflR and nor-1 genes, PCR indicated that the gene does not exist in this isolate Table (3). This may be due to the fact that the ver-1 gene encodes an enzyme a ketoreductase which is required for the conversion of versicolorin A to desmethyl sterigmatocystin (DMST) in the aflatoxin biosynthetic pathway [26]. The presence of the ver-1 gene, which is in charge of the production of aflatoxins, was shown in 10 isolates of the A. flavus from a total of 15 isolates as in figure (3). Where it was noted that the site of the gene appeared in the sequence (600 bp) when the primer ver-1 was used.

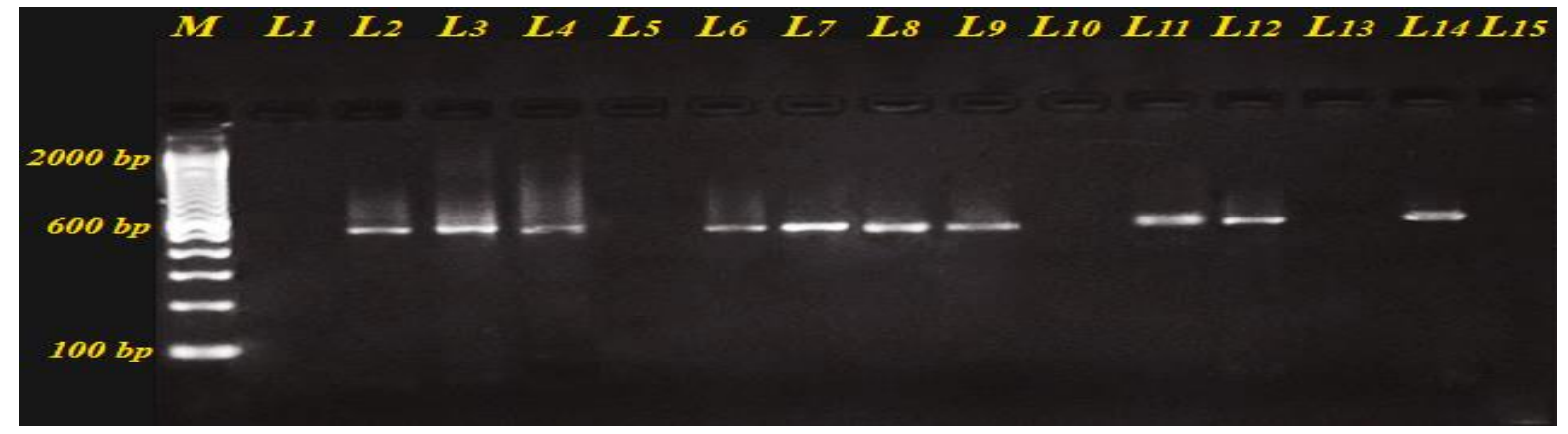

Fig. (3): PCR product with ver-1 primer (ver-1 gene) on $1.5 \%$ agarose gel electrophoresis with ethidium bromide, M: 100 bp DNA ladder. Lanes: AFl1, AFl2, AFl3, AFl4, AFl5, AFl6, AFl7, AFl8, AFl9, AFl10, AFl11, AFl12, AFl13, AFl14, AFl15.

This result corresponds with the findings of Hamed et al., (2016). The findings of these studies were in agreement with the results of previous studies on the chain of DNA sequence that belongs to the gene ver-1 appropriate design significant primer to diagnose fungi producing aflatoxins [27]

The aflR primer pairs were selected to detect the aflatoxigenic isolates of A.flavus in the PCR technique as a marker because this gene has importance in the biosynthesis of aflatoxin, amplification of aflR gene targeted by PCR and electrophoresis. The results revealed that the ability of 10 isolates out of 15 isolates to produce AF through the gene aflR which is responsible for regulating the AF biosynthetic process. Figure (4) showed the PCR products $(1000 \mathrm{pb})$.

Although these specific primers to amplify the expected bands from the isolates produced for aflatoxin, great variability was usually found in their aflatoxigenic capacity tested by the HPLC method which showed that it was not a sufficient marker for differentiation between aflatoxigenic and some non-aflatoxigenic isolates. The lack of aflatoxin production could also be due to simple mutations (substitution of some bases) which lead to the formation of nonfunctional products. Lack of aflatoxin production apparently can also be related to the incomplete pattern obtained in PCR [28,29]. 


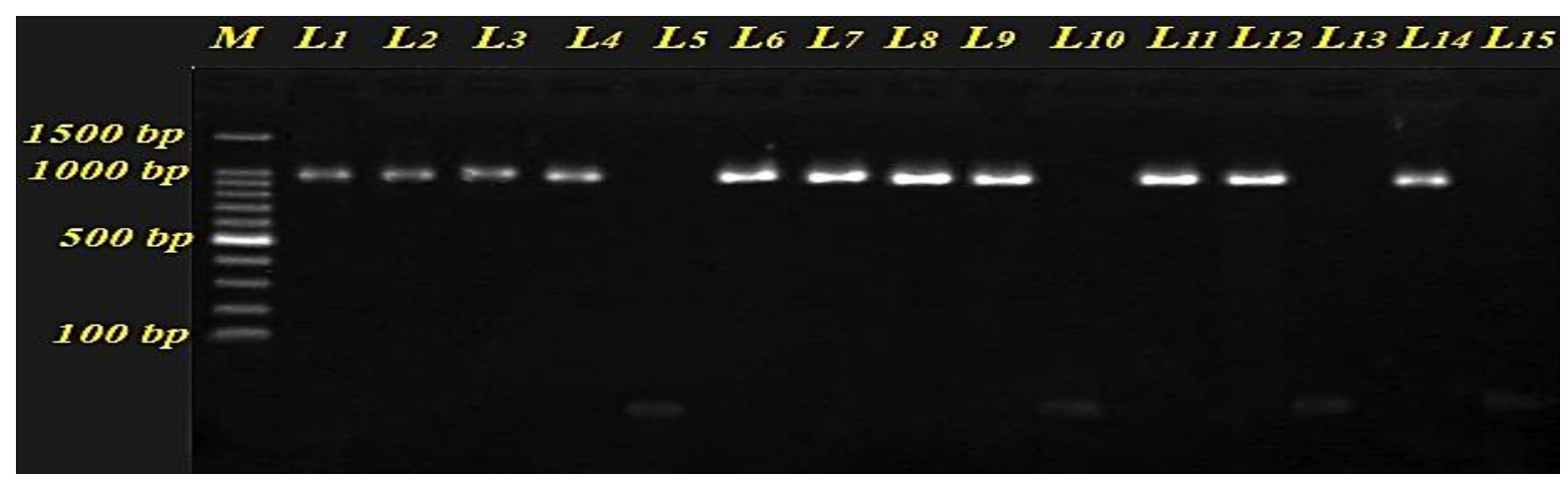

Fig. (4): PCR product with an aflR primer on $1 \%$ agarose gel electrophoresis with ethidum bromide, M: 100 bp DNA ladder. Lanes: AFl1, AFl2, AFl3, AFl4, AFl5, AFl6, AFl7, AFl8, AFl9, AFl10, AFl11, AFl12, AFl13, AFl14, AFl15.

The biosynthetic pathway includes many enzymatic steps including aflatoxins as the end product. Notwithstanding earlier work, there is yet to be detected a definite marker for producing aflatoxins, inde pendent from their measurement [30]. Several studies have reported the use of PCR technique as a sensitive and rapid method for detection and determination of aflatoxin production [31] and identifying aflatoxigenic isolate from non-aflatoxigenic isolate [18]. PCR analysis was capable to amplify regulatory gene aflR and two structural genes i.e. nor-1 and ver-1 and by using specifically designed primers. The aflR is the positive regulatory gene which acts required for transcription activation of most of a structural gene [26].

In this study, 10 isolates out of 15 were aflatoxigenic when examined by PCR analysis. As it was noted, nor-1 gene was amplified in most of the isolates as it was a structural gene required in the step of initial for biosynthesis pathway of aflatoxin. Three primers were thoroughly selected to be very specific for these three genes perceived to be necessary for aflatoxin biosynthesis. This primer pair yielded a single DNA fragment of the predicted size of 400, 600 and $1000 \mathrm{bp}$ for (nor-1, ver-1 and aflR) respectively. Interestingly, all the ten isolates were able to confirm the aflatoxin production by using HPLC. This technique have been used as a strategy to confirm aflatoxin production from isolates which show amplification of three genes (nor-1, ver-1 and aflR), but with the unsteady level of success which can be accomplished by many attempts by using PCR [32].

HPLC has been recognized as a standard and superior method in the identification and analyzing aflatoxin with higher sensitivity and accuracy in comparis on with other methods [6]. The isolates of the study were examined by using HPLC techniques with the ultraviolet radiation detector at a wavelength of $365 \mathrm{~nm}$. The results showed the ability of most isolates of A. flavus to produce AFB1, as it gained the value of the retention time (RT) for each of the inoculated samples of extract and the sample of the standard solution B1 (7.30) minutes figure (5).

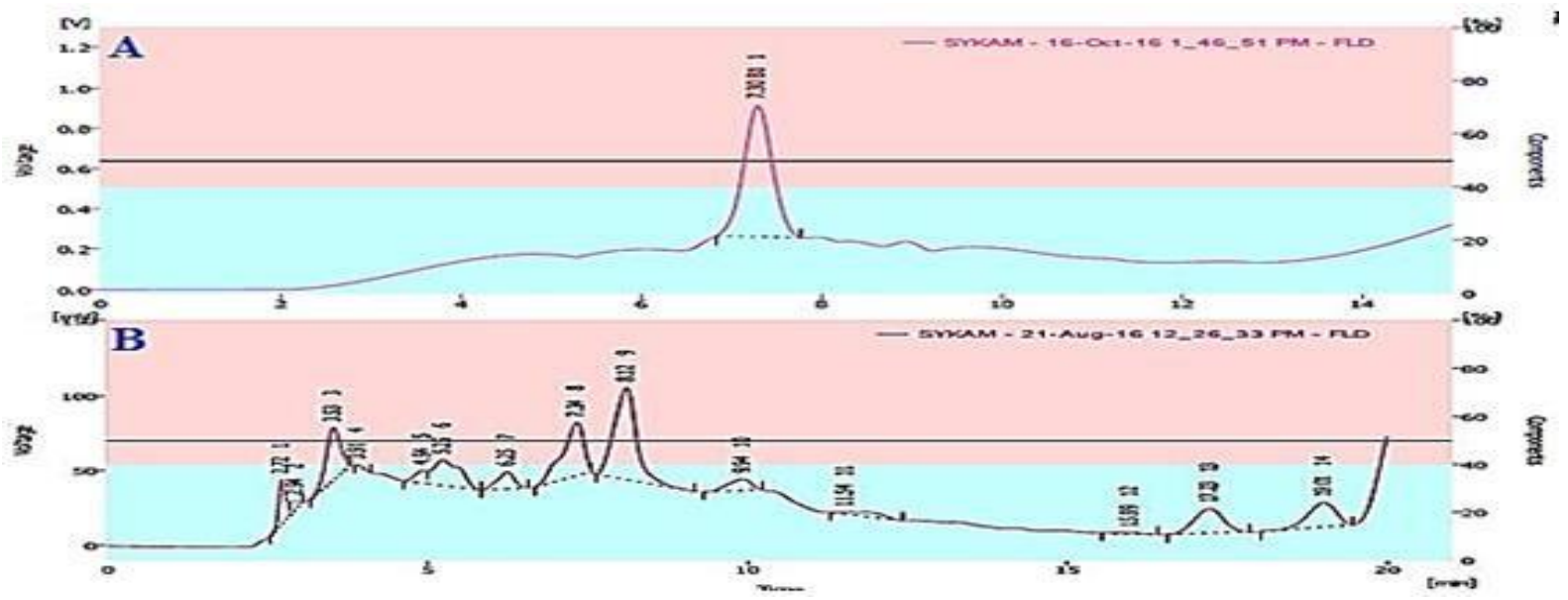

Fig. (5): Detection of AFB1 extracted from Aspergillus flavus by HPLC, the Standard chromatogram of AF (A): (Total Run Time: 14 minutes Retention time for AFB1: 7.30 minutes), (B): Chromatogram of various AF in $A$. flavus 
The study results obtained from HPLC revealed that non-aflatoxigenic isolates were less detected than aflatoxigenic isolates. Also, aflatoxin production is directly associated with the appearance of genes (ver-1, nor1, and aflR) [23]. The analysis of HPLC results indicated that A. flavus in peanut produced the highest concentration of aflatoxin Blat a rate of $45.03 \mathrm{ppm}$ while the rate of A. flavus in crude oil was $0.78 \mathrm{ppm}$ (least rates of aflatoxin B1 Table (3).

Aflatoxigenic activity in the environmental and clinical isolates was tested in which 10 samples out of 15 gave the positive results for aflatoxin contamination. Non-aflatoxigenic isolates showed different patterns by noting no amplification. All the isolates having less than three target DNA fragments were deemed to be nonaflatoxigenic.

Table (3): Distribution the results of HPLC and gene detection by PCR according to study fungal isolates from clinical and environmental origin.

\begin{tabular}{|c|c|c|c|c|c|}
\hline \multirow{2}{*}{ Isolate No. } & \multirow{2}{*}{ Isolate origin } & \multirow{2}{*}{$\begin{array}{l}\text { Co. AFB1 in } \\
\text { HPLC (ppm) }\end{array}$} & \multicolumn{3}{|c|}{ Aflatoxin genes } \\
\hline & & & $a f l R$ & nor-1 & ver-1 \\
\hline AFL1 & Fish & $0.00 \pm 0.00$ & + & + & - \\
\hline AFL2 & Lung of animal & $11.66 \pm 0.75$ & + & + & + \\
\hline AFL3 & Spices & $12.55 \pm 0.87$ & + & + & + \\
\hline AFLA & Rice & $8.35 \pm 0.63$ & + & + & + \\
\hline AFL5 & Animal waste & $0.00 \pm 0.00$ & - & - & - \\
\hline AFL6 & Corn grain & $33.86 \pm 2.04$ & + & + & + \\
\hline AFL7 & Crude oil & $0.78 \pm 0.01$ & + & + & + \\
\hline AFL8 & Barley grain & $6.24 \pm 0.58$ & + & + & + \\
\hline AFL9 & Wheat & $29.89 \pm 1.93$ & + & + & + \\
\hline AFL10 & Bovine Milk & $0.00 \pm 0.00$ & - & - & - \\
\hline AFL11 & Fruits & $17.39 \pm 1.26$ & + & + & + \\
\hline AFL12 & Nuts & $12.66 \pm 0.73$ & + & + & + \\
\hline AFL13 & Poultry lung & $0.00 \pm 0.00$ & - & - & - \\
\hline AFL14 & Peanut seeds & $45.03 \pm 2.59$ & + & + & + \\
\hline AFL15 & Vegetables & $0.00 \pm 0.00$ & - & - & - \\
\hline
\end{tabular}

${ }^{a}$ means presence of PCR amplification signal, ${ }^{b}$ means absence of PCR amplification signal

HPLC study results agreed completely with those obtained by molecular technique, PCR. There was a relationship between the result of the study of PCR and HPLC technique. Thakar et al., (2017) stated that the lack of aflatoxin production can be a result of the substitution of some nitrogen bases. Also, Ibrahim et al., (2016) concluded that various physiologic conditions can be effective in aflatoxin biosynthesis. In this study, it was observed PCR may be considered as a screening test for initial isolation regarding high sensitivity and speed $(100 \%)$. The positive samples need more investigation by an efficient technique such as HPLC.

In this study, it is concluded that PCR technique is proved to be the accurate and rapid detection system in discrimination between aflatoxigenic and non-aflatoxigenic isolates of A. flavus on the basis of amplification of the target DNA fragments that are involved in aflatoxin production. Further, aflatoxin production is directly associated with an appearance of genes (ver-1, nor-1, and aflR). The present study demonstrated that all the ten isolates of A. flavus which showed amplification in three of genes and were able to confirm the aflatoxin production when they are diagnosed by using HPLC, this technique is standard and superior in identifying and analyzing aflatoxin with high sensitivity and accuracy.

\section{Acknowledgments}

Great gratitude is due to the laboratory staff of Ministry of Science and Technology, and College of Veterinary Medicine - University of Baghdad as well as the teaching staff members of College of Pharmacy, University of Anbar for their full-time support during this project.

\section{References}

1. Abdel-Hadi, A. M., Caley, D. P., Carter, D. R. F. and Magan, N. (2011). Control of aflatoxin production of Aspergillus flavus and Aspergillus parasitics using RNA silencing technology by targeting aflD (nor-1) gene. Toxins. 3:647-59.

2. Hamed, S., Murad, A. F. and Abdul-Rahim, E.A. (2016). Molecularly diagnostic of Aflatoxigenic Aspergillus flavus isolated from nuts. Res J Environ Toxicol. 10:1-11. 
3. Levin, R.E. (2012). PCR detection of aflatoxin producing fungi and its limitations. Int J Food Microbiol. 156:16.

4. Rodrigues, P., Gil-Serna, J. and González-Jaén, M.T. (2017). Evaluating Aflatoxin gene expression in Aspergillus section flavi. Bus Media LLC.1542:237-47.

5. Jamali, M., Karimipour, M., Shams-ghafarokhi, M. and Amani, A. (2013). Expression of aflatoxin genes aflO (omtB) and aflQ (ordA) differentiates levels of aflatoxin production by Aspergillus flavus strains from soils of pistachio orchards. Res Microbiol. 164:293-9.

6. Hussain, A., Afzal, A., Irfan, M. and Malik, K. A. (2015). Molecular detection of Aflatoxin-producing strains of Aspergillus flavus from peanut (Arachis Hypogaea). Turkish J. Agric - Food Sci Technol. 3:335-341.

7. Luque, M. I., Rodriguez, A., Andrade, M. J. and Martin, A. (2012). Development of a PCR protocol to detect Aflatoxigenic molds in food products. J. Food Prot. 75:85-94.

8. Obestatin, S., Blesab, J., Moltób, J. C., Ghorbela, A. and Mañesb, J. (2014). Presence of mycotoxins in sorghum and intake estimation in Tunisia. Food Addit Contam Part A. 31:318-307 .

9. Duniere, L., Xu, S., Long, J., Elekwachi, C., Wang, Y. and Turkington, K. (2017). Bacterial and fungal core microbiomes associated with small grain silages during ensiling and aerobic spoilage. BMC Microbiol. 17:5066.

10. Diba, K., Rezaie, S. and Mahmoudi, M. (2007). Identification of Aspergillus species using morphological characteristics. Public Health. 23:867-72.

11. Paul, J. S., Tiwari, K.L. and Jadhav, S. K. (2015). Long term preservation of commercial important fungi in glycerol at $4^{\circ} \mathrm{C}$. Int J Biol Chem. 9:79-85.

12. Lahouar, A., Marin, S., Crespo-empire, A. and Saïd, S. (2016). Effects of temperature, water activity and incubation time on fungal growth and aflatoxin B1 production by toxinogenic Aspergillus flavus isolates on sorghum seeds. Microbiología. 48:78-85.

13. Hooi, H.L. and Sali, S.A. (2014). Bioprocessing of agricultural residuals for the optimum production of extracellular Xylanase by Aspergillus Brasilian is in solid state fermentation. Biodiversity, Bioprospecting Dev.1:121-136.

14. Miyamoto, K., Murakami, T. and Kakumyan, P. (2014). Formation of 1-octen-3-ol from Aspergillus flavus conidia is accelerated after disruption of cells independently of Ppo oxygenases and is not the main cause of inhibition of germination. Peer J. 1-12.

15. Lai, X., Zhang, H., Liu, R. and Liu, C. (2015). Potential for aflatoxin B1 and B2 production by Aspergillus flavus strains isolated from rice samples. Saudi J. Biol. Sci. 22:176-80.

16. AOAC Official Method 971. 24. (2000). Aflatoxins in coconut, copra, and copra meal. Natural Toxins chapter 49. Official Methods of Analysis of AOAC International, 17th edition, volume I, AOAC International, Gaithers burg, Maryland, USA: 14-15.

17. Abdel-Hadi, A., Carter, D. and Magan, N. (2011). Discrimination between aflatoxigenic and non-aflatoxigenic strains of Aspergillus section Flavi group contaminating Egyptian peanuts using molecular and analytical techniques Ahmed. World Mycotoxin J. 4:69-77.

18. Rashid, M., Khalil, S., Ayub, N., Ahmed, W. and Khan, A. G. (2008). Categorization of Aspergillus flavus and Aspergillus parasitic isolates of stored wheat grains into aflatoxigenic and not-aflatoxigenic. Pakistan J. Bot. 40:2177-92.

19. SAS, (2012). Statistical analysis system, user's guide statistical. Version $9.1^{\text {st }}$ ed. SAS. Inst. Inc. Cary. NC, USA.

20. Quinn, P.J., Carter, M.G., markey, B. and Carter, G.R. (2013). Clinical veterinary microbiology; M. Wlof; London. 192-196.

21. Karlovsky, P., Suman, M., Berthiller, F., Meester, J. De., Eisenbrand, G. and Perrin, I. (2016). Impact of food processing and detoxification treatments on mycotoxin contamination. Mycotoxin Res. 32:179-205.

22. Sultan, Y. and Magan, N. (2010). Mycotoxigenic fungi in peanuts from different geographic regions of Egypt. Mycotoxin Res. 26: 133-140.

23. Pildain, B.M., Frisvad, J.C., Vaamonde, G., Cabral, D., Varga. J. and Samson R.A. (2008). Two novel aflatoxinproducing Aspergillus species from Argentinean peanuts. Intl. J. Syst. and Evol. Microbiol. 58: 725-735.

24. Al-saad, L.A., Al-Badran, A.I. and Al-jumpy, S.A. (2016). The impact of bacterial biocontrol agents on aflatoxin biosynthetic genes, aflD and aflR expression, and phenotypic aflatoxin B1 production by Aspergillus flavus under different environmental and nutritional regimes. Int J Food Microbiol. 217:123-129.

25. Rouhani, H. and Chang, P.K. (2014). Gene deletion patterns in non-aflatoxigenic strains of Aspergillus flavus. Mycol Iran. 1:87-97.

26. Yu, J. (2012). Current understanding on Aflatoxin biosynthesis and future perspective in reducing Aflatoxin contamination. Toxins. 7:1024-57.

27. Fakruddin, M., Chowdhury, A., Hossain, M.N. and Ahmed, M.M. (2015). Characterization of aflatoxinproducing Aspergillus flavus from food and feed samples. Springerplus. 4:159.

28. Moubasher, H., Taleb, A.A. and Senousy, H.H. (2015). Molecular differentiation between Aflatoxigenic and 
nonAflatoxinogenic strains of Aspergillus flavus and Aspergillus parasitics. Microbiology. 82:642-642.

29. Moubasher, M.H., Taleb, A.A. and Aljaeed, H.M. (2016). Expression of Aflatoxin genes Nor-1, Ont-B, Ott-A, and Ord-A to Differentiate between Aflatoxigenic and Non-Aflatoxigenic strains of Aspergillus Flavus and Aspergillus parasiticus M. Microbiol Biotechnol. 3:232-245

30. Rodrigues, P., Venencio, A., Kozakiewicz, Z. and Lima, N. (2009). A polyphasic approach to the identification of aflatoxigenic and non-aflatoxigenic strains of Aspergillus section Flavi isolated from Portuguese almonds. Intl. J. Food Microbiol, 129: 187-193.

31. Hadi, A.A., Carter, D. and Magan, N. (2011). Discrimination between aflatoxigenic and non-aflatoxigenic Aspergillus section Flavi strains from Egyptian peanuts using molecular and analytical techniques. World Myco. J. 4: 69-77.

32. Rodrigues, P., Soares, C., Kozakiewicz, Z., Paterson, R.R.M., Lima, N. and Venâncio, A. (2014). Identification and characterization of Aspergillus flavus and aflatoxins. IN: Méndez-Villas A. (Editor) - "Communicating Current Research and Educational Topics and Trends in Applied Microbiology". Formatex. 3:527-534.

33. Thakar, D., Zhang, J. and Wing, R.A. (2017). Aflatoxin-free transgenic maize using host-induced gene silencing. Sci Adv. 3. 233-244.

34. Ibrahim, F., Hina, J.A. and Khan, M. (2016). Prevalence of Aflatoxigenic Aspergillus in food and feed samples from Karachi, Pakistan. J Infect Mol Biol Preval. 4:1-8. 